\title{
EDITORIAL
}

\section{EI Lado Desconocido de las Plantas Transgénicas}

\author{
The unknown side of transgenic plants
}

Wilson Huanca-Mamani

Dr. en Ciencias con Especialidad en Biotecnología de Plantas. Laboratorio de Biotecnología Vegetal, Departamento de Producción Agrícola, Facultad de Ciencias Agronómicas, Universidad de Tarapacá. E-mail: whuanca@uta.cl

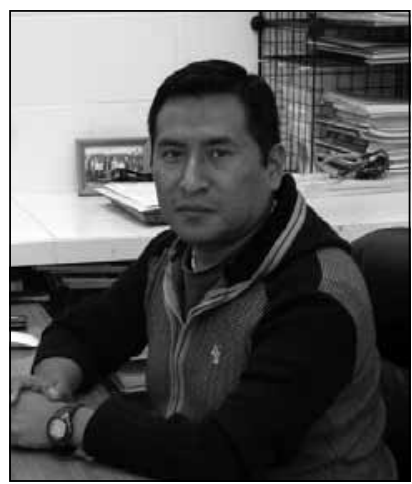

$\mathrm{Ph}$. D. in Plant Biotechnology Laboratory of Plant Biotechnology, Department of Agriculture Production, Faculty of Agricultural Science University of Tarapacá E-mail:whuanca@uta.cl
Las plantas transgénicas, o genéticamente modificadas, son aquellas a las cuales se les ha introducido material genético propio o extraño por métodos de ingeniería genética. La utilización aplicada de las plantas transgénicas está enfocada a mejorar ciertas características de los cultivos, como aumentar la resistencia a plagas, a herbicidas y la tolerancia a estrés abióticos, entre otros, lo que genera un impacto económico, ya que estas características ventajosas están destinadas principalmente a aumentar los niveles de producción del cultivo.

El mejoramiento genético clásico de plantas, mediado por cruzas, comenzó hace unos 10.000 años, en cambio, las primeras plantas transgénicas se obtuvieron sólo hace 30 años y esta nueva forma de manipulación de seres vivos ha levantado polémica y rechazo infundado por parte de la sociedad, básicamente debido a que los riesgos que implica el uso de esta tecnología no han sido aclarados y divulgados por la comunidad científica. Actualmente, las plantas transgénicas destinadas para cultivo son los productos agrícolas analizados con mayor rigurosidad de toda la historia de la agricultura.

Las plantas transgénicas se utilizan también para hacer investigación científica y esta actividad es desconocida por la opinión pública, no tiene impacto económico inmediato; sin embargo, gracias a ella se han podido descifrar procesos biológicos claves,
Transgenic or genetically modified plants are those in which genetic engineering has been used to introduce genetic material, from their own or from another species. The application of transgenic plants is focused on improving specific characteristics of crops, such as increased resistance to pests and herbicides and tolerance to abiotic stresses, among others. This generates an economic impact, since these advantageous characters are produced mainly to improve crop production levels.

Classical genetic improvement of plants by crossing between them probably began 10000 years ago; however, the first transgenic plants were produced only 30 years ago. This new form of manipulating live organisms has caused controversy and unjustified rejection by part of society, mainly due the fact that the risks involved in the use of this technology have not been clearly divulged by the scientific community. Transgenic plants produced for crops are analyzed with more rigor than any agricultural product in all previous agricultural history.

Transgenic plants are also used in scientific research; although this is unknown by the general public since it has no immediate economic impact, it is thanks to this research that we have been able to understand key biological processes which are 
que son importantes para la vida. Un análisis genético clásico se basa en la observación de mutantes de una especie con un fenotipo dado y el uso de estrategias para correlacionar ese fenotipo mutante con un gen en particular; de la mutante al gen. Sin embargo, con la utilización de plantas transgénicas se ha desarrollado una estrategia denominada "genética reversa", la cual sigue una lógica "reversa" al análisis clásico; del gen a la mutante. En esta estrategia se aísla un gen y su función se identifica a través del fenotipo que se produce al generar una planta transgénica, en la cual la actividad de ese gen está alterada, mediante su sobreexpresión o silenciamiento. Estas plantas han permitido rotular genes a nivel molecular, mediante la introducción de secuencias "etiquetas" de elementos móviles como transposones o mediante secuencias de T-DNA de la bacteria Agrobacterium tumefaciens.

Como aporte a la investigación científica se han destacado exitosamente en los laboratorios durante las dos últimas décadas, debido a que han permitido el progreso rápido en la comprensión de la biología de las plantas. Mediante ellas se ha conocido el circuito de genes reguladores responsables del control de la transición floral y del desarrollo de flores y frutos, de forma que es posible planificar el tiempo de floración de las cosechas y la modificación de caracteres como el color, el aroma o el valor nutritivo. La biología del desarrollo de las plantas ha pasado de ser una disciplina netamente descriptiva a otra muy activa, se están identificando genes y sus interacciones en procesos claves como la formación de gametos, la embriogénesis, la formación de hojas o la especificación celular en las raíces y tallos. En el estudio de la respuesta a estrés abiótico, se ha podido identificar genes que responden a la salinidad, a la sequía, al frío, a metales como el boro y aluminio entre otros, lo que permitirá establecer las bases genéticas y los mecanismos que regulan la tolerancia a estos estrés.

El silenciamiento génico mediado por ARN, es un mecanismo adaptativo que induce la formación de defensas antivirales sistémicas, en respuesta a la presencia de un virus. Este mecanismo regulatorio fue descrito de forma reciente y caracterizado inicialmente en plantas antes que en animales. A partir de estos estudios se desarrolló una tecnología que permite estudiar la función de genes, denominada RNAi (RNA de interferencia), la que consiste en la generación de plantas transgénicas que portan una construcción que producirá moléculas específicas important to life. Classical genetic analysis is based on the study of mutations in a species which produce a specific phenotype and the use of strategies to correlate this mutant phenotype with a specific gene; thus it proceeds from the mutant to the gene. The use of transgenic plants has allowed the development of a strategy called reverse genetics, which follows an inverse logic to that of classical analysis; that is, it proceeds from the gene to the mutant. In this strategy a gene is isolated; its function is then identified by determing the phenotype produced when a transgenic plant is produced in which the activity of this gene is altered, by overexpression or by silencing. These plants have allowed genes to be tagged molecularly, by the introduction of "tag" sequences of mobile elements such as transposons, or with T-DNA sequences of the bacterium Agrobacterium tumefaciens.

These transgenic plants have produced highly successful results as a tool for scientific research in the last few decades, since they have allowed rapid progress in the understanding of the biology of plants. Their use has allowed understanding the circuit of regulatory genes responsible for flower initiation and the development of flowers and fruits, making it possible to plan the flowering times of crops and modify characters such as color, aroma or nutritional value. Plant developmental biology has gone from being a purely descriptive discipline to a very active area in which genes and their interactions are being identified in key processes such as gamete formation, embryogenesis, leaf formation and cell specification in roots and stems. In the study of abiotic stress, genes have been identified which affect the response of plants to salinity, drought, cold and metals such as boron and aluminum, among others, which will soon allow us to establish the genetic bases and mechanisms that regulate tolerance to these stresses.

Gene silencing mediated by RNA is an adaptive mechanism which induces the formation of systemic antiviral defenses as a response to the presence of a virus. This regulatory mechanism was recently described in plants, before it was described in animals. Based on these studies a technique was developed that allows the study of gene function called RNA $i$ (RNA interference), which consists of producing transgenic plants that carry a construction which 
RNA de cadena doble, capaces de inhibir la expresión de genes endógenos de manera sumamente selectiva.

El uso de plantas transgénicas en investigación científica ha sido un elemento fundamental para la generación de conocimiento básico, si bien a nivel aplicado el uso de esta tecnología tiene sus detractores, nadie puede negar el enorme impacto y desarrollo que ellas han producido y continuarán produciendo en la biología vegetal. will produce specific molecules of double-stranded RNA that is highly selective.

The use of transgenic plants in scientific research has been a fundamental element in the generation of basic knowledge. Although at the applied level the use of this technology has its detractors, no one can deny the enormous impact and development that their use has produced and will continue to produce in plant biology. 
